\title{
LARIX GENUS GROWING RATE AND ASSOCIATION WITH METEOROLOGICAL CONDITIONS IN THE BOTANICAL GARDEN OF KLAIPĖDA UNIVERSITY, LITHUANIA
}

\author{
KLIMIENĖ, A.* - NORMANTÉ, L. - KLIMAS, R. \\ Klaipeda University, H. Manto str. 84, 92294 Klaipeda, Lithuania \\ *Corresponding author \\ e-mail: asta.klimiene@ku.bs; phone: +370-61-460-520 \\ (Received $14^{\text {th }}$ Feb 2018; accepted $24^{\text {th }}$ May 2018)
}

\begin{abstract}
The most important climate parameters in dendrochronological investigation are air temperature and dynamics of precipitation in certain periods. In the research time from 2005 to 20163 species and 2 hybrids: Larix sibirica, L. decidua, L. kaempheri, L. x gmelinii and L. x eurolepis were evaluated in the Botanical Garden of Klaipeda University, that is situated in the western part of Lithuania. This region can be characterized with high precipitation in the summer season, warm air temperature in winter and the lowest temperature values are in the summer season. According to research data the precipitation in autumn season influenced the highest radial growths of all observed Larix ( $\mathrm{r}$ from 0,33 to 0,78 ), but average air temperature in this season had no influence ( $\mathrm{r}$ from $-0,19$ to 0,50 ), similarly temperature had no influence in the spring season either ( $\mathrm{r}$ from $-0,12$ to $-0,76, \mathrm{p}<0.001$ ). $62 \%$ of $L$. sibirica was influenced by precipitation but $22 \%$ of L. decidua by air temperature in the autumn season. The average radial growth of hibrid larches, namely L. $x$ gmelinii and $L$. x eurolepis was $1.3-1.5$ times lower compared with $L$. sibirica and $L$. decidua . L. $x$ gmelinii and $L$. x eurolepis were also positively influenced by precipitation in the autumn season.
\end{abstract}

Keywords: botanic garden, Larix, average temperature, precipitation, season, radial growth

\section{Introduction}

Tree rings analysis is widely used in modern forest lumbering, climate change research and in forest monitoring studies (Worbes, 2004). Most important climate parameters in dendrochronological investigation are air temperature and dynamics of precipitation content in certain periods (Xue et al., 2016). In Lithuanian conditions the formation of annual tree rings is mostly influenced by air temperature in active vegetation period (April - September) and precipitation in the summer time (Stravinskiene, 2002). Climate is a major environmental factor affecting the phenotype of trees and a critical agent of natural selection that has molded among-population genetic variation. Population response functions describe the environmental effect of planting site climate on the performance of a single population, whereas transfer functions describe among-population genetic variation molded by natural selection for climate. Although these approaches are widely used to predict the responses of trees to climate change, both have limitations (Wang et al., 2010). The rapid rate of change coupled with the large absolute amount of change are expected to have profound effects on terrestrial ecosystems at all hierarchical levels: from vegetation zones (Tchebakova et al., 2005), to ecosystems (Guisan et al., 1995), species (Fujiwara and Box, 1999), and to populations within species (Rehfeldt et al., 1999, 2002; Tchebakova et al., 2005).

Larch (Larix) belongs to the Pinaceae family and is one of the most abundant coniferous genera of the northern hemisphere. The larches - Larix P. Mill. - of the world are usually grouped into 10 species that are widely distributed in Eurasia and North America (Hora, 1981; Krüssmann, 1985; Schmidt, 1995; Farjon, 2010; Ide et al., 2016). Some species 
dominate at the northern limits of boreal forests and others occur above subalpine forests (Gower and Richards, 1990). Larch cannot grow in the shade. It prefers moist soil. The plant can tolerate maritime exposure, they cannot tolerate atmospheric pollution (http://www.pfaf.org). Geographic races have developed in many widely distributed larch species, and these often exhibit marked differences in growth rates and other characteristics (Rudolf, 1974; Bednarova et al., 2013). The European larch includes at least 5 geographic races (often considered to be subspecies or varieties) that roughly coincide with major distributional groups of the species. European larch (Larix decidua, Miller, 1768) is endemic to Europe and is characterized by a disjunctive distribution (Wagner, 2013). European seed sources perform similarly in northeastern United States as in Great Britain, Germany and Italy (Dylis, 1981). Some varieties of Dahurian larch that is confined to definite areas appear to be geographic races. The native western larch specimens from more continental climates with lower humidity are doing poorly. European larch compared with other species can be characterized with faster growth. Natural habitat of European larch is relatively small and covers mainly the European mountainous regions (Busetto et al., 2010). The rapid growth of larch, high productivity and sustainability are achieved when soil and climatic conditions are in accordance with the biological requirements. The dry weather, hot summers and cold winters are important conditions for larch (Тимофеев, 1961). Larix sibirica is common in the lowland taiga of West Siberia, where it forms the northern limit of trees alternately with Picea obovata and with Pinus sylvestris. Larrix also occurs in the mountains (from $500 \mathrm{~m}$ to 2,400 $\mathrm{m}$ a.s.l.). It grows on a great variety of soils, from peat bogs to well drained, sandy or rocky soils, where it has its optimum, that is in very cold climate (min. temp. $-55^{\circ} \mathrm{C}$ ), continental or subarctic, dry, with very long winters. There are stands on peat or on mountains above the steppe (Altai Mts.), but more common it is mixed with Pinus sylvestris, P. sibirica, Picea obovata, Abies sibirica and broad-leaved trees such as Betula pendula and Populus spp (Farjon, 2013). Japanese larch (Larix kaempferi) is one of the most important timber species in the sub-Alpine region and northern area of Japan (Zhu et al., 1998). Larix gmelinii (Rupr.) is one of the most economically important species in boreal forests (Zyryanova et al., 2007). It is a deciduous needleleaf conifer that is adapted to growing in very harsh climates and is widely distributed over a range from $40^{\circ} \mathrm{N}$ to $72^{\circ} \mathrm{N}$ and $110^{\circ} \mathrm{E}$ to $130^{\circ} \mathrm{E}$ (Zhu et al., 1998). It is the dominant tree species in the Greater Khingan Mountains forest ecosystem in northern China (Farjon, 1990; Fu et al., 1999).

Introduction of European larch (Larix decidua Mill.) in Lithuania launched in the middle of the XIX century as a valuable industrial and decorative species. In forestries of the country larch began to grow 160 years ago, and now grow such forest stand in south part of Lithuania in Alytus district (Navasaitis, 2004). As in natural habitats, in Lithuania larches resistant to cold, and not affected by winter (Pūkienè and Bitvinskas, 2000). In Lithuania European larch mainly grows in mixed stands associated with Norway spruce (Picea abies), stone pine (Pinus cembra), Swiss pine (Pinus mugo), European beech (Fagus sylvatica) or silver fir (Abies alba) but can also occur in pure stands (Navasaitis, 2004).

The stem radial growth of trees in any year integrates the effects of the climate during the previous and current year (Zhang and Chen, 2015; Jiang et al., 2016). Tree radial growth is influenced by environmental factors (e.g., temperature, precipitation, and competition) and conditions within the individual tree (Zhang and Chen, 2015). Tree-ring records are often used to investigate the responses of tree growth to historical climate variations, to predict the effects of future climate change on tree growth, and to understand the spatial and temporal patterns of tree-growth variability of forest ecosystems (Thuiller et al., 2005; Tardif et al., 2006; Metsaranta et al., 2008). Stem sensitivity growth rate is an important indicator for the 
assessment to increasing annual radial gain and their connection with environmental conditions (Karpavičius, 2004). Reasearch of Larix genus growing intensity is important to climate changes context in botanical gardens, because there ussualy carry out evaluating of plants acclimatization. This is important to preserve biological diversity and educate the society. Many people may have a conceptual grasp of climate change, but may not know what climate effects to expect in the region, and what impacts climate change may have on their day-to-day environment. As the urgency and significance of climate change continues to mount, new approaches are needed for interpreting and visualizing climate change for the public that is tangible and approachable. Botanical gardens have made longstanding contributions to climate change research, particularly with respect to temperature and its effects on the timing of plant flowering and leaf out by participating in phenological networks of botanical gardens, monitoring standardized plantings in phenological gardens, and studying and examining herbarium specimens and historical photographs (Primack and MillerRushing, 2009).

The aim of this work is to evaluate Larix Mill genus plant radial growth in the context of climate parameter changes in the Botanical Garden of Klaipeda University located in the west part of Lithuania (coastal zone).

\section{Material and methods}

\section{Study area and object}

The Botanical Garden of Klaipeda University is located in Western Lithuania, in the northern part of the city of Klaipeda, in the valley of the Dane River. It was established in 1993, since 2002 it has dendrological park status. In general, the width of the area is 9.3 ha, and collections of ornamental plants are established here. The most important purpose of the Botanical Garden is the conservation of the genetic resources of herbaceous and woody ornamental and medicinal plants in the collections. It is a unique plant introduction centre, where climatic conditions differ from other parts of Lithuania, because of having higher air temperature, more precipitation, and a longer plant-vegetation period. Therefore, these are favourable conditions for plant adaptation. Since 2005, Botanical Garden is a member of the International Phenological Gardens (IPG).

In the Dendrological section of the Botanical Garden 10 taxa of Larix P. Mill. are growing. For research 3 species and 2 hybrids of larches were evaluated: Larix sibirica, $L$. decidua, L. kaempheri, L. x gmelinii and L. x eurolepis (3 individuals from every taxa). The age of the evaluated larix were different: $L$. sibirica was $19, L$. decidua was $14, L$. kaempheri was 13, L. x gmelinii was 14, L. x eurolepis was 10 years old. In this research radial growth of stems were compared during the period of 2005-2016.

All plants were growing in the same soil type, namely FLc-ar (Fluvisol AreniCalcicaric). The texture of soil at $0.30 \mathrm{~m}: 84.8 \%$ sand, $9.4 \%$ dust, $5.8 \%$ clay. The soil $\mathrm{pH}$ is 6.2 , mobile phosphorus concentration is $581 \mathrm{mg} / \mathrm{kg}$, mobile potassium concentration is $135 \mathrm{mg} / \mathrm{kg}$, total nitrogen $-0.114 \mathrm{mg} / \mathrm{L}$, biohumus content is $2.05 \%$.

\section{Dendrochronological investigation}

Dendrochronological investigation of larch tree stems was done by the methodological recommendation of Stravinskienè, 2005. Experimental bore was carried out in March from 2015-2017 with Pressler borer. $1.30 \mathrm{~m}$ height was bored from tree root mouth, to the same north-east direction. In total 15 trees were bored. For the 
evaluation measuring system LINTAB was used with computer programme WinTSAP 0.30 (F. Rinn Engineering Office and Distribution, Heidelberg, Germany), the accuracy of the measurement was $0.001 \mathrm{~mm}$. The quality and synchronity of dating between lines of radial growth was measured by COFECHA 3.00 programme. Non synchronic examples remained undetermined.

\section{Meteorological data}

The average monthly and annual data of climate factors (air temperature and precipitation) was supplied by the Lithuanian Hydrometeorological Service (LHS) under the Ministry of Environment, Department of Klaipeda. Distance between LHS and Klaipeda University Botanical Garden is approximately $3 \mathrm{~km}$. Data were presented from 2005 to 2016. In this period in January -June precipitation content was from 30 to $50 \mathrm{~mm}$ per month in average, but in July - December $100 \mathrm{~mm}$ and more per month (Fig. 1). During the period of 2005-2016 negative air temperatures usually are fixed in January and February (from -1.5 to $-1.8{ }^{\circ} \mathrm{C}$ respectively), the highest annual air temperature in this period was in June - September months (from 14.6 to $18.9^{\circ} \mathrm{C}$ ) (Fig. 2).

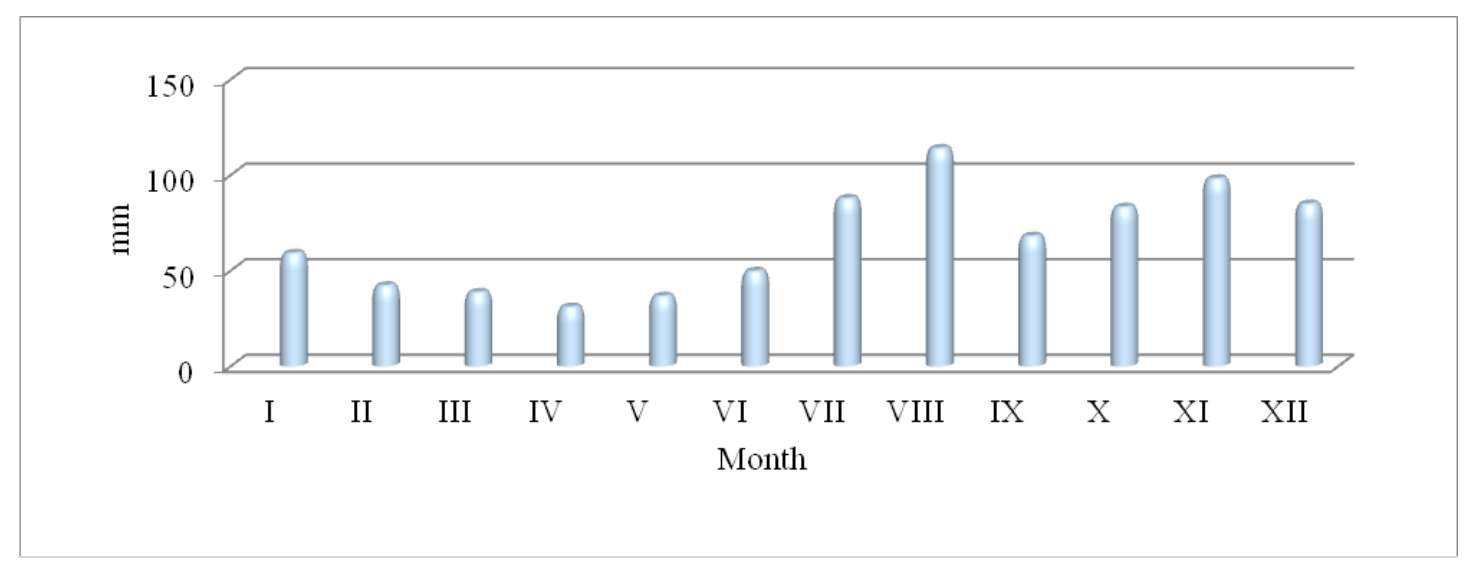

Figure 1. Distribution of precipitation (mm), average in 2005-2016. Data of Klaipeda meteorological station

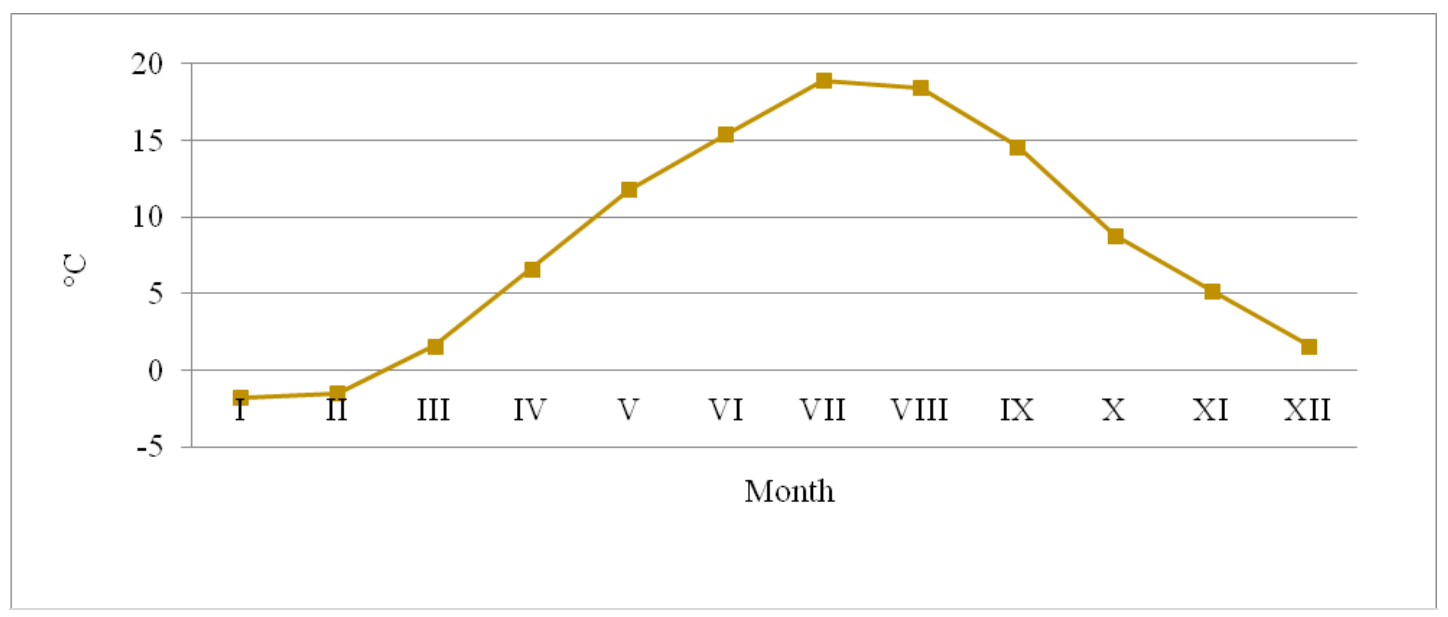

Figure 2. Average air temperature $\left({ }^{\circ} \mathrm{C}\right)$ in 2005-2016. (Data of Klaipeda meteorological station) 


$$
-4423-
$$

\section{Statistical analysis}

The experimental data were processed using statistical package SPSS version 17.0. Interrelationship between radial growth (width of tree - ring) and precipitation and air temperature were estimated. Correlation ( $r$ ) and regression (R) was considered significant when $\mathrm{P}<0.05$.

\section{Results}

Annual air temperature and precipitation and humidity are important factors in plants growing rate and productivity. The values and linear trend of means of annual precipitation and air temperature in four seasons are presented in Figure 3 and 4. The total precipitation was the highest in the summer time $(3014.5 \mathrm{~mm})$. In other seasons this indicator was $1273.5 \mathrm{~mm}, 2890 \mathrm{~mm}$ and $2145.9 \mathrm{~mm}$ in the spring, in the autumn and in the winter, respectively.

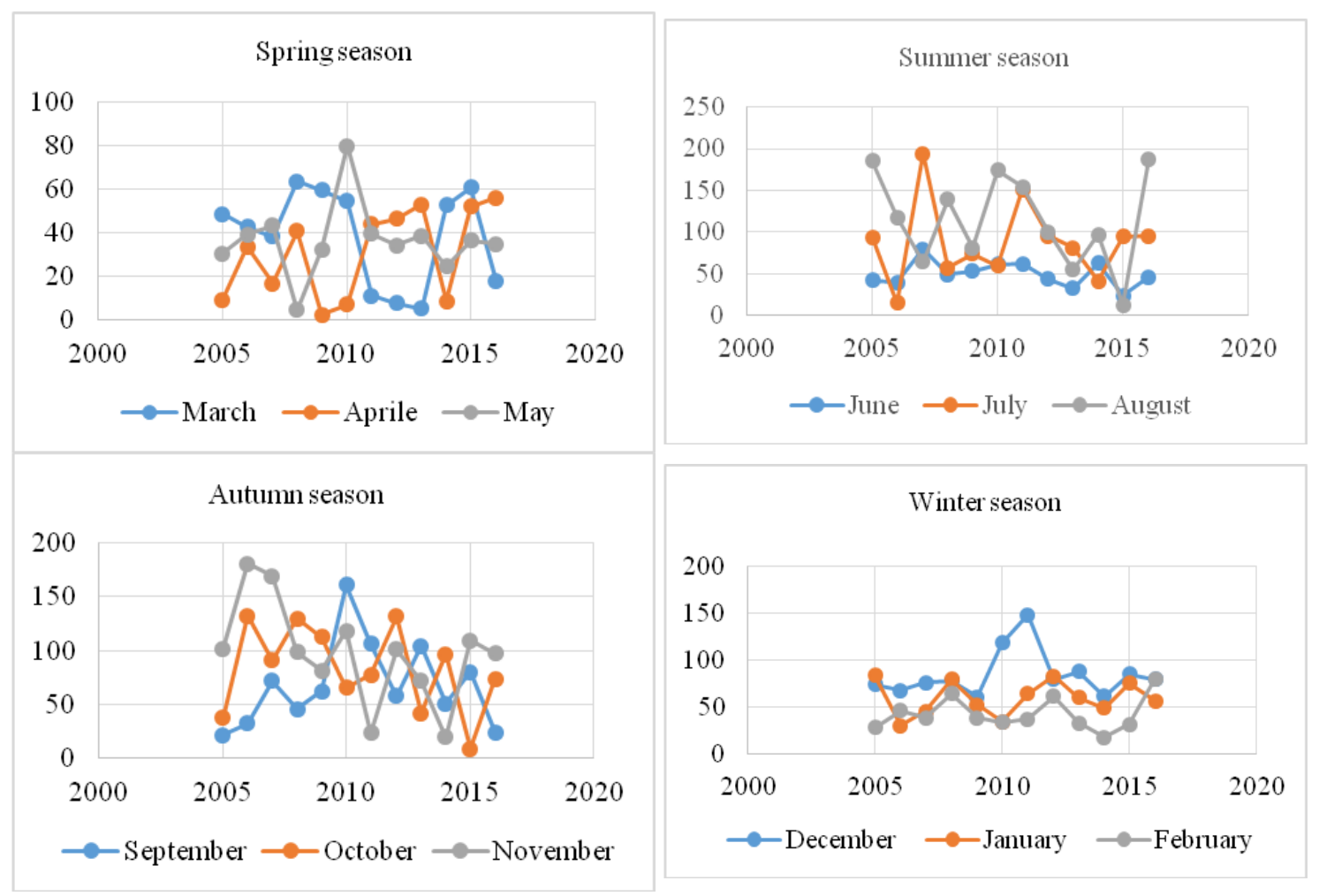

Figure 3. Distribution of precipitation (mm) in seasons. (Klaipéda, 2005-2016)

In the period of $2005-2016$ the highest precipitation in spring was in 2010 and 2015 years (respectively $141.6 \mathrm{~mm}$ and $149.4 \mathrm{~mm}$ ). The lowest amount of precipitation was in $2014(86.1 \mathrm{~mm})$. The exclusive summer season was in 2015 , when precipitation was only $130.5 \mathrm{~mm}$ and in 2011 when it was over $366.5 \mathrm{~mm}$. In the autumn season the

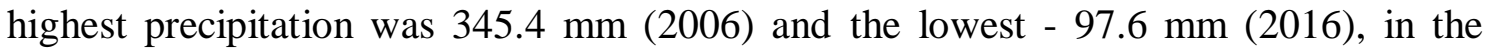
winter season the highest content $248.5 \mathrm{~mm}$ (2011) and the lowest $135.9 \mathrm{~mm} \mathrm{(2016)}$.

If range of temperatures per season (Fig. 4) are compared, the highest temperature in spring was in $2014\left(8.1^{\circ} \mathrm{C}\right)$ and the lowest in $2005\left(4.9^{\circ} \mathrm{C}\right)$. The summer and autumn 
seasons haven't important fluctuations per period. Temperature in the summer is in average $17.5^{\circ} \mathrm{C}$ (from $16.8^{\circ} \mathrm{C}$ in 2012 to $18.4{ }^{\circ} \mathrm{C}$ in 2010) and in the autumn it was the lowest in $2010\left(8^{\circ} \mathrm{C}\right)$ and the highest in $2011\left(10.3^{\circ} \mathrm{C}\right)$. Winter season was mutable per period: temperature ranged from - 5.4 (2010) to $2.3{ }^{\circ} \mathrm{C}$ (2015), but mostly was about 0 ${ }^{\circ} \mathrm{C}$, in average it was $-0.7^{\circ} \mathrm{C}$ per period.
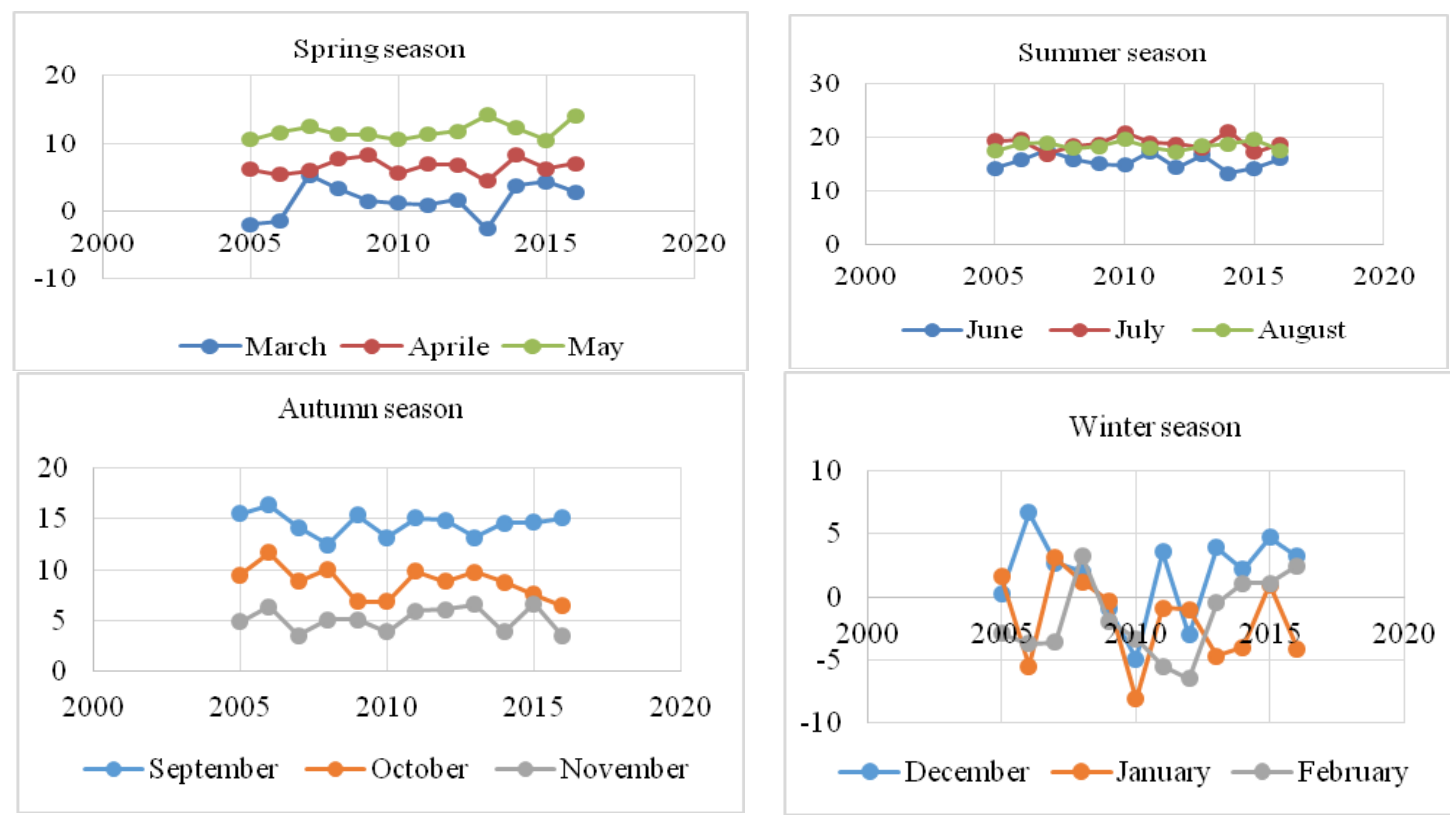

Figure 4. Distribution of average air temperature $\left({ }^{\circ} \mathrm{C}\right)$ in seasons. (Klaipeda, 2005-2016)

All larches growing rapidly are lush and vital. L. sibirica is the oldest in the Botanical Garden, it is 19 years old and the diameter of its stem is $40 \mathrm{~cm}$. L. decidua and L. $x$ gmelinii are 14 years old and their average stem diameter is $30 \mathrm{~cm}$. The meteorological conditions (precipitation and air temperature) individually influenced the radial growth rate of different Larix species in separate years (Table 1).

For observing plants per period was investigate, unequal growth of stem rings (Fig. 5). Per period the highest radial growth of $L$. sibirica was in 2006 and 2012 years $-11.5 \mathrm{~mm}$, but the lowest in 2014 only $4.5 \mathrm{~mm}$. Very similar tendencies can be observed in L. decidua: the highest radial growth $(11.5 \mathrm{~mm})$ was in 2006 year and the lowest $(3.7 \mathrm{~mm})$ in 2013. L. kaempferi growth rate in 2014 was $10.00 \mathrm{~mm}$ (its highest increase) and the lowest - $5 \mathrm{~mm}$ determine in 2013, 2015 and 2016 as well. In L. $x$ gmelinii and L. $x$ eurolepis the highest value of this indicator was $9.3 \mathrm{~mm}$ in 2008 and $7.3 \mathrm{~mm}$ in 2011, but the lowest in 2016 to both species, $4.3 \mathrm{~mm}$ and $3.0 \mathrm{~mm}$, respectively. Statisticaly significant and negative correlation (Table 2) between radial growth and precipitation was found mostly in the spring season related to L. sibirica, L. kaempferi, L. $x$ gmelinii and $L$. $x$ eurolepis, but in the summer and winter seasons it can be related to L. decidua. Positive, but statistically unreliable correlation between mentioned parameters in all species of larch was determined only in the autumn season. Statistically significant and negative correlation between radial growth and air temperature in L. sibirica was established in the spring, summer and winter seasons, in L. decidua only in the spring season, in $L$. kaempferi in the autumn and winter seasons, in hybrids of L. x gmelinii and L. x eurolepis in the spring and autumn seasons. Very similar and statistically significant dependences 
are also shown regression coefficients (Table 3). To be noted, that statistically more significant relationships ( $\mathrm{r}$ and $\mathrm{R}$ ) in the investigated larches were determined between radial growth and temperature than between radial growth and precipitation. Thus, a tendency that annual air temperature makes more influence on the width of tree rings than annual precipitation can be observed. However, according to research data, in autumn season on the radial growth of $L$. sibirica precipitation positive affected by $62 \%(\mathrm{y}=$ $\left.0.0245 \mathrm{x}+2.6459 ; \mathrm{R}^{2}=0.6216\right)$, of $L$. $x$ eurolepis - by $53 \%\left(\mathrm{y}=0.0148 \mathrm{x}+1.7703 ; \mathrm{R}^{2}=\right.$ $0.5256)$ and of L. x gmelinii - by $39 \%\left(\mathrm{y}=0.0119 \mathrm{x}+3.6817 ; \mathrm{R}^{2}=0.3925\right)$.

Table 1. Characteristics of meteorological conditions influencing the radial growth rate of different Larix species. (Klaipéda, 2005-2016)

\begin{tabular}{|c|c|c|c|c|}
\hline \multirow[b]{2}{*}{ Larix species } & \multicolumn{2}{|c|}{$\begin{array}{c}\text { Years with fixed possitive radial growth } \\
\text { rate (higher than average) }\end{array}$} & \multicolumn{2}{|c|}{$\begin{array}{l}\text { Years with fixed negative radial growth } \\
\text { rate (lower than average) }\end{array}$} \\
\hline & Years & $\begin{array}{l}\text { Characteristic of } \\
\text { meteorological } \\
\text { conditions }\end{array}$ & Years & $\begin{array}{c}\text { Characteristic of } \\
\text { meteorological conditions }\end{array}$ \\
\hline L. sibirica & $\begin{array}{l}2006-2008 \\
2010-2012\end{array}$ & $\begin{array}{c}\text { The warm and wet } \\
\text { autumn, warm beginning } \\
\text { winter season }\end{array}$ & $\begin{array}{l}2005,2009 \\
2013,2014- \\
2016\end{array}$ & $\begin{array}{c}\text { Air temperature and } \\
\text { precipitation satisfy with } \\
\text { the multi-annual averages, } \\
\text { the excess humidity in } \\
\text { August }\end{array}$ \\
\hline L. decidua & $\begin{array}{l}2006,2009 \\
2014,2015\end{array}$ & $\begin{array}{l}\text { Humidity November, } \\
\text { positive average } \\
\text { temperature in March, } \\
\text { warm December }\end{array}$ & $\begin{array}{l}2007,2008 \\
2010-2013 \\
2016\end{array}$ & $\begin{array}{l}\text { Warm and humidity } \\
\text { autumn, deficiency } \\
\text { precipitation in summer } \\
\text { season }\end{array}$ \\
\hline L. kaempferi & 2007-2011, 2014 & $\begin{array}{c}\text { The warm and wet } \\
\text { autumn, warm beginning } \\
\text { winter season }\end{array}$ & $\begin{array}{l}2012,2013 \\
2015,2016\end{array}$ & Dry autumn season \\
\hline Larix $x$ gmelinii & 2006-2008, 2011 & $\begin{array}{c}\text { The warm and wet } \\
\text { autumn, warm beginning } \\
\text { winter season }\end{array}$ & $\begin{array}{l}2009,2010 \\
2012-2016\end{array}$ & $\begin{array}{l}\text { High air temperature and } \\
\text { dry summer season }\end{array}$ \\
\hline Larix $x$ eurolepis & $2010-2013$ & $\begin{array}{l}\text { Humidity spring and } \\
\text { autumn season }\end{array}$ & $2014-2016$ & $\begin{array}{l}\text { High air temperature and } \\
\text { dry summer season }\end{array}$ \\
\hline
\end{tabular}

Table 2. Correlation between tree-ring width and precipitation and air temperature

\begin{tabular}{c|c|c|c|c|c|c|c|c}
\hline \multirow{2}{*}{ Larix name } & \multicolumn{4}{|c|}{ Precipitation in seasons, mm } & \multicolumn{4}{c}{ Temperature in seasons, ${ }^{\circ} \mathbf{C}$} \\
\cline { 2 - 9 } & Spring & Summer & Autumn & Winter & Spring & Summer & Autumn & Winter \\
\hline L. sibirica & $-0,02^{* *}$ & 0.27 & 0.78 & 0.35 & $-0.23^{* *}$ & $-0.46^{* *}$ & 0.13 & $-0.38^{* *}$ \\
\hline L. decidua & 0.07 & $-0.32 * *$ & 0.33 & $-0.42^{* *}$ & $-0.20^{* *}$ & 0.10 & 0.50 & 0.06 \\
\hline L. kaempferi & $-0.42^{* *}$ & 0.43 & 0.37 & $0.02 *$ & 0.27 & 0.47 & $-0.45^{* *}$ & $0.13^{* *}$ \\
\hline L. x gmelinii & $-0.05^{* *}$ & 0.09 & 0.64 & 0.41 & $-0.12^{* *}$ & 0.14 & $-0.20^{*}$ & 0.37 \\
\hline L. x eurolepis & $-0.01 * *$ & 0.44 & 0.72 & 0.79 & $-0.76^{* *}$ & 0.44 & $-0.29 * *$ & -0.58 \\
\hline
\end{tabular}

Note: $* \mathrm{P}<0.05 ; * * \mathrm{P}<0.001$ 
Table 3. Regression between tree-ring width and precipitation and air temperature

\begin{tabular}{c|c|c|c|c|c|c|c|c}
\hline \multirow{2}{*}{ Larix name } & \multicolumn{4}{|c|}{ Precipitation in seasons, mm } & \multicolumn{4}{c}{ Temperature in seasons, ${ }^{\circ} \mathbf{C}$} \\
\cline { 2 - 9 } & Spring & Summer & Autumn & Winter & Spring & Summer & Autumn & Winter \\
\hline L. sibirica & $-0.13^{* *}$ & 9.14 & 27.05 & 5.81 & $-0.11^{* *}$ & 0.05 & 0.05 & $-0.36^{* *}$ \\
\hline L. decidua & 0.72 & $-12.40^{* *}$ & 13.21 & $-8.36^{* *}$ & $-0.11^{* *}$ & $0.02^{*}$ & 0.25 & 0.07 \\
\hline L. kaempferi & $-4.7^{* *}$ & 17.67 & 14.38 & 0.49 & 0.13 & 0.12 & $-0.19^{* *}$ & $-0.16^{*}$ \\
\hline L.x gmelinii & $-0.79^{* *}$ & 4.99 & 35.63 & 11.65 & $-0.09^{* *}$ & $0.04^{*}$ & $-0.13^{* *}$ & 0.58 \\
\hline L.x eurolepis & $-0.21^{* *}$ & 23.29 & 35.40 & 20.84 & $-0.48^{* *}$ & 23.29 & $-0.16^{* *}$ & $-0.88^{* *}$ \\
\hline
\end{tabular}

Note: $* \mathrm{P}<0.05 ; * * \mathrm{P}<0.001$

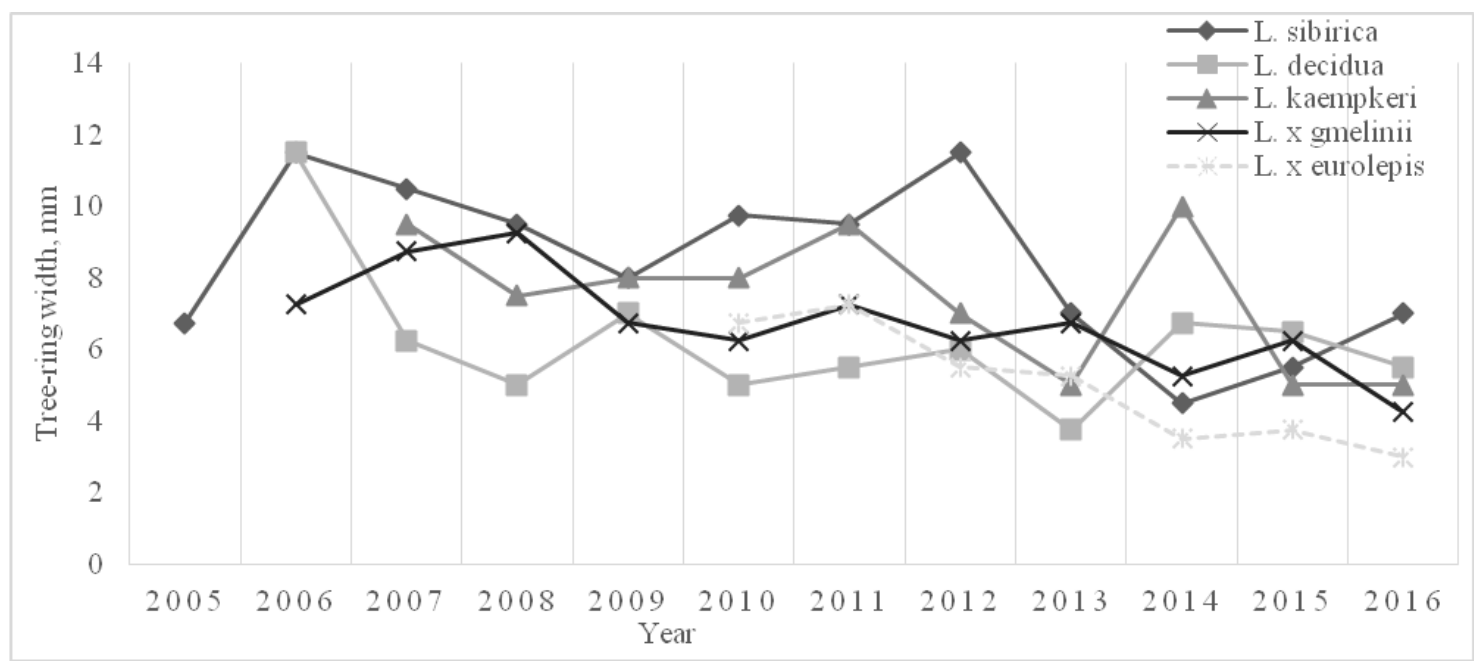

Figure 5. Average width of tree-ring of different larix species. (Klaipéda, 2005-2016)

\section{Discussion}

Larch cannot grow in the shade. It prefers moist soil. The plant can tolerate maritime exposure, they cannot tolerate atmospheric pollution (http://www.pfaf.org). In the Klaipeda University Botanical Garden are favourable conditions for larches to grow and cultivate. In the optimal conditions the climatic factors correlation with annual rings of trees radial gains are negligible, however in worse growing conditions a higher increasing effect on the formation of annual radial rings is noticed (Läänelaid, 1996). In the research period from 2005 - 2016 in the Botanical Garden of Klaipeda University the radial growth ranged from 3 to $11.5 \mathrm{~mm}$ in average (Fig. 5). The highest precipitation (Fig. 3) was in 2007 (925 mm), $2010(966 \mathrm{~mm})$ and $2011(917.5 \mathrm{~mm})$ and the lowest in $2014(581.6 \mathrm{~mm})$, the temperature (Fig. 4) had its highest value in 2008 and $2015,9.1$ and $9.0^{\circ} \mathrm{C}$, respectively and the lowest in 2010 , only $6.7^{\circ} \mathrm{C}$. For larches in Lithuanian conditions active vegetation begins in the middle of April and ends in the middle of October, in this period air temperature usually ranges from 12.0 to $15.8{ }^{\circ} \mathrm{C}$, in average perennial air temperature was $12,8{ }^{\circ} \mathrm{C}$. Winter and spring seasons air temperature for Larix radial growth is very important too (Karpavičius and Kaselyte், 2000). In Klaipeda, costal area it is noticed, that in spring and winter seasons air temperature and precipitation are unequal, but in summer season they are smooth. Average temperature in summer season is $17.5{ }^{\circ} \mathrm{C}$ (in the spring, autumn and winter seasons were $6.7^{\circ} \mathrm{C} ; 9.7^{\circ} \mathrm{C}$ and $-0.7^{\circ} \mathrm{C}$, respectively). By the evaluation of data of larches in 
the spring season statistically significant correlation between tree-ring width and precipitation (Table 2) be found for all Larix except for L. decidua. The correlation and regression between tree-ring and precipitation in autumn season was statistically insignificant for all Larix (Table 2, 3). If compared in the winter season, the statistically significant correlation between tree-ring width and precipitation were only true for $L$. decidua $(\mathrm{P}<0.001)$ and L. kaempferi $(\mathrm{P}<0.05)$, but tree-ring width and air temperature only for L. sibirica $(\mathrm{P}<0.001)$ and L. kaempferi $(\mathrm{P}<0.001)$. In the spring and winter seasons precipitation was $1273.5 \mathrm{~mm}$ and $2145.9 \mathrm{~mm}$, respectively.

The annual hybrid larix radial growth in Estonia was $3.5 \mathrm{~mm}$, the highest value was 13 $\mathrm{mm}$. The high rings width of young age of larix show that it is hybrid and had good environmental conditions (Sander and Läänelaid, 2007). In Poland, the annual radial growth showed more dependence from the amount of precipitation in summer season (Oleksyn and Fritts, 1991). Evaluating all larches in the Botanical Garden, only L. decidua in the summer season showed significant negative correlation (Table 2). In the summer season height regression between tree-ring width and precipitation for all larix too, but statistically significant value was only for $L$. decidua $(\mathrm{P}<0.001)$. The influence of precipitation on the radial growth of larch across Lithuania is usually positive but more variable than the relationships with air temperature (Karpavičius and Kaselyte, 2000).

Temperature requirements of European larch regarding the onset of individual phenological stages were evaluated based on the sums of air temperatures above $0{ }^{\circ} \mathrm{C}$ and of effective air temperatures higher than $+5{ }^{\circ} \mathrm{C}$ (Bednarova et al., 2013). Efficient growth and good adaptation of European larch and Larix deciduas subsp. Polonica in Lithuania can be associated with the northern habitat border. The increased air moisture, relatively warm winters and cool summers are factors that European larch can much better endure. In addition, European larch grows very rapidly during the growing season, it takes up much more water than other conifers and larch is one of the most sun-loving tree species (Karpavičius, 2004). In Lithuanian climate conditions the L. decidue radial growth is mostly influenced by the warm and dry summer season (Karpavičius, 2004). Sensitivity of growth rate of $L$. decidua was $0.35 \pm 0.01$ (Karpavičius, 2004). European larch grows very rapidly during the growing season, it takes up much more water than other conifers and larch is one of the most sun-loving tree species. Average radial growth of L. decidua pursue $2.18 \pm 0.04 \mathrm{~mm}$. The period of $1850-2007$ was a distinguished time when $70-90 \%$ from all evaluating trees average radial growth was bigger compared with multi - annual average. It is observed that more wood gained in years with warm spring and warm winter (Stravinskienė and Erlickytė, 2003; Vitas and Žeimavičius, 2006; Vitas, 2011). In west Lithuania due the research period the radial growth fluctuate from $6.25 \pm 0.02 \mathrm{~mm}$ of $L$. decidua, $8.46 \pm 0.02 \mathrm{~mm}-$ L. sibirica, $7.45 \pm 0.02 \mathrm{~mm}-$ L. kaempferi, $6.75 \pm 0.01 \mathrm{~mm}-L$. $x$ gmelinii and $5 \pm 0.01 \mathrm{~mm}-$ L. $x$ eurolepis. The Botanical Garden is good environmental condition for Larix to grow and in west Lithuania climate parameters as temperature and precipitation are favorable too.

\section{Conclusions}

1. According to research data in the west Lithuania (costal area) the highest precipitation per evaluating period was in the summer time $3014.5 \mathrm{~mm}$, the lowest in the spring, $1273.5 \mathrm{~mm}$. The mutable temperature per period was in the winter season from -5.4 to $2.3{ }^{\circ} \mathrm{C}$. The air conditions for growing of Larix genus is good but for some species is a too big amount of precipitation. 
2. After the evaluation of 5 taxa of larches, it was established, that on the radial growth the climate parameters (precipitation and air temperature) in separate seasons influenced the larches individually. Hybrid larches L. $x$ gmelinii and $L$. $x$ eurolepis average radial growth was $1.3-1.5$ times lower compared with $L$. sibirica and L. decidua. It means, that lower radial width are for pure species rather than for hybrids.

3. Positive, but statistically unreliable correlation between radial growth and precipitation in all species of larch was only in the autumn season. Usually autumn precipitation can more influencing on the growing quality in next year.

4. Noted, that more statistically significant relationships ( $r$ and $R$ ) in the investigated larches was determined between radial growth and temperature than between radial growth and precipitation. Thus, there is a tendency that annual air temperature makes more influence on the width of tree - rings than annual precipitation.

\section{REFERENCES}

[1] Bednarova, E., Slovikova, K., Truparova, S., Merklova, L. (2013): Results of a phenological study of the European larch (Larix decidua Mill.) growing in a mixed stand. - Acta Univ Agric Silvic Mendelianae Brun 61: 1239-1246.

[2] Busetto, L., Colombo, R., Migliavacca, M., Cremonese, E., Meroni, M., Galvagno, M., Rossini, M., Siniscalco, C., Morra di Cella, U., Pari, E. (2010): Remote sensing of larch phenological cycle and analysis of relationships with climate in the Alpine region. Global Change Biology 16: 2504-2517.

[3] Dylis, N. V. (1981): Larch. - Moscow, Forestry Industry Press.

[4] Gower, S. T., Richards, J. H. (1990): Larches: deciduous conifers in an evergreen world. - BioScience 40(11): 818-826.

[5] Guisan, A., Theurillat, J.-P., Spichiger, R. (1995): Effects of Climate Change on Alpine Plant Diversity and Distribution: The Modeling and Monitoring Perspectives. - In: A. Guisan, J. I. Holten., R. Spichiger., L. Tessier (eds.) Potential Ecological Impacts of Climate Change in the Alps and Fennoscandian Mountains. Conservatoire et Jardin Botaniques de Geneve, Switzerland.

[6] Ide, R., Oguma, H., Hirose, Y., Takahashi, Y., Saigusa, N. (2016): Phenological changes for 10 years and the influence on ecosystem productivity in a larch forest at the foot of Mt. Fuji. - Japan Geoscience Union Meeting, Proceedings 2016(22): 10.

[7] Jiang, Y., Zhang, J., Han, S., Chen, Z., Setälä, H., Yu, J., Zheng, X., Guo, Y., Gu, Y. (2016). Radial growth response of Larix gmelinii to Climate along a latitudinal gradient in the Greater Khingan Mountains, Northeastern China. - Forests 7: 295.

[8] Farjon, A. (1990): Pinaceae. - Koeltz Scientific Books, Konigstein, Germany.

[9] Farjon, A. (2010): A Handbook of the World's Conifers. - Koninklijke Brill, Leiden.

[10] Farjon, A. (2013): Larix sibirica. The IUCN Red List of Threatened Species. International Union for Conservation of Nature, UK.

[11] Fu, L. K., Li, N., Mill, R. R. (1999): Larix. - In: Wu, Z. Y., Raven, P. H. (eds.) Flora of China. Science Press, Beijing, China. Missouri Botanical Garden Press, St. Louis, MI, USA, pp. 33-37.

[12] Fujiwara, K., Box, E. O. (1999): Evergreen Broad-Leaved Forests in Japan and Eastern North America: Vegetation Shift under Climatic Warming. - In: Klötzli, F., Walther, G. R. (eds.) Conference on Recent Shifts in Vegetation Boundaries of Deciduous Forests, Especially Due to General Global Warming. Monte Verità (Proceedings of the Centro Stefano Franscini Ascona). Birkhäuser, Basel. 
[13] Hora, F. B. (1981): Larches (genus Larix). - In: Hora, B. (ed.) The Oxford Encyclopedia of Trees of the World. Oxford University Press, Oxford, UK, pp. 76-79.

[14] http://www.pfaf.org/user/Plant.aspx?LatinName=Larix+decidua.

[15] Karpavičius, J. (2004): Skirtingų medžių rūšių radialiojo prieaugio savitumai ir jų priklausomybè nuo ịvairių veiksnių. - Ekologija 4: 23-31.

[16] Karpavičius, J., Kaselytè, A. (2000): Maumedžių ir vietinių rūšių (pušies, ąžuolo) radialinio prieaugio priklausomybė nuo klimato veiksnių. - Dendrologia Lithuaniae V. Vilnius, pp. 54-60.

[17] Krüssmann, G. (1985): Larix. - In: Manual of Cultivated Conifers. Timber Press, Portland, OR, pp. 157-163.

[18] Läänelaid, A. (1996): Tree-ring dating in Estonia: The roof of the Nõo church. Dendrochronologia 14: 217-221.

[19] Metsaranta, J. M., Lieffers, V. J., Wein, R. W. (2008): Dendrochronological reconstruction of jack pine snag and downed log dynamics in Saskatchewan and Manitoba, Canada. - For. Ecol. Manag. 255: 1262-1270.

[20] Navasaitis, M. (2004): Maumedis. - Dendrologija, Vilnius, pp. 169-173.

[21] Oleksyn, J., Fritts, H. C. (1991): Influence of climatic factors upon tree rings of Larix deciduas and L. deciduas $\times$ L. kaempferi from Pulawy, Poland. - Trees 5(2): 75-8.

[22] Primack, R. B., Miller-Rushing, A. J. (2009): The role of botanical gardens in climate change research. - New Phytologist 182: 303-313.

[23] Pūkienè, R., Bitvinskas, T. (2000). Europinio maumedžio (Larix Decidua Mill.) radialinio prieaugio kaitą lemiantys aplinkos veiksniai. - Dendrologia Lithuania 5: 72-77.

[24] Rehfeldt, G. E., Ying, C. C., Spittlehouse, D. L., Hamilton, D. L. (1999): Genetic responses to climate in Pinus contorta: Niche breadth, climate change and reforestation. Ecological Monographs 69: 375-407.

[25] Rehfeldt, G. E., Tchebakova, N. M., Parfenova, Y. I., Wykoff, W. R., Kouzmina, N. A., Milyutin, L. I. (2002): Intra specific responses to climate in Pinus sylvestris. - Global Change Biology 8: 1-18.

[26] Rudolf, P. O. (1974): Larix Mill., Larch. - In: Schopmeyer, C. S. (ed.) Seeds of Woody Plants in the United States. Agric. Handbk. USDA Forest Service, Washington, DC, pp. 478-485.

[27] Sander, H., Läänelaid, A. (2007): The Dunkeld larch (Larix x marschlinsii Coaz) in Estonia. - Dendrobiology 57(1): 73-80.

[28] Schmidt, W. C. (1995): Around the World with Larix: An Introduction. - In: Schmidt W. C., McDonald, K. J. (eds.) Ecology and Management of Larix Forests: A Look Ahead. Whitefish, MT. Gen. Tech. Rep. INT-319. Proceedings, International Symposium; 1992 October 5-9. USDA Forest Service, Intermountain Research Station, Ogden, UT, pp. 618.

[29] Stravinskienè, V. (2002): Klimato veiksnių ir antropogeninių aplinkos pokyčių dendrochronologinè indikacija. - Lutute, Kaunas (in Lithuanian).

[30] Stravinskienè, V., Erlickytè, R. (2003): Growth of scots pine (pinus sylvestris 1.) in the vicinity of the of "Akmenès cementas" plants. - Ecology 4: 34-39.

[31] Tardif, J. C., Conciatori, F., Nantel, P., Gagnon, D. (2006): Radial growth and climate responses of white oak (Quercus alba) and northern red oak (Quercus rubra) at the northern distribution limit of white oak in Quebec, Canada. - J. Biogeogr. 33: 1657-1669.

[32] Tchebakova, N. M., Rehfeldt, G. E., Parfenova, E. I. (2005): Redistribution of vegetation zones and populations of Larix sibirica Ledeb. and Pinus sylvestris L. in Central Siberia in a warming climate. - Siberian Ecological Journal 10: 677-686 (in Russian).

[33] Thuiller, W., Lavorel, S., Arujo, M. B., Sykes, M. T., Prentice, I. C. (2005): Climate change threats to plant diversity in Europe. - Proc. Natl. Acad. Sci. 102: 8245-8250.

[34] Тимофеев, В. П. (1961): Роль лиственницы в поднятии продуктивности лесов. АНСССР, Москва (in Russian). 
[35] Vitas, A., Žeimavičius, K. (2006): Trends of decline of douglas fir in Lithuania: dendroclimatological approach. - Baltic Forestry 12(2): 200-206.

[36] Wagner, S. (2013): History of the European larch (Larix decidua Mill.). - Doctoral Thesis, University of Bordeaux.

[37] Wang, T., O’Neill, G. A., Aitken, S. A. (2010): Integrating environmental and genetic effects to predict responses of tree populations to climate. - Ecological Applications 20(1): 153-163.

[38] Worbes, M. (2004): Mensuration. Tree Rings Analysis. - In: Burley, J. et al. (eds.) Encyclopaedia of Forest Sciences. Elsevier, Amsterdam, pp. 586-599.

[39] Xue, B. L., Guo, Q., Gong, Y., Hu, T., Liu, J., Ohta, T. (2016): The influence of meteorology and phenology on net ecosystem exchange in an eastern Siberian boreal larch forest. - Journal of Plant Ecology 9(6): 1-11.

[40] Zhang, X., Chen, Z. (2015): A new method to remove the tree growth trend based on ensemble empirical mode decomposition. - Trees 31(2): 405-413.

[41] Zhu, J., Nakano, T., Hirakawa, Y. (1998): Effect of growth on wood properties for Japanese larch (Larix kaempfer): Differences of annual ring structure between corewood and outer wood. - J Wood Sci 44: 392-396.

[42] Zyryanova, O. A., Yaborov, V. T., Tchikhacheva, T. L., Koike, T., Makoto, K., Matsuura, Y., Zyryanov, V. I. (2007): The structure and biodiversity after fire disturbance in Larix gmelinii (Rupr.). - Eurasian J. For. Res. 10: 19-29. 